\title{
THE EFFECTIVENESS OF TECHNOLOGY, PEDAGOGY AND CONTENT KNOWLEDGE (TPACK) IN LEARNING
}

\author{
Nalurita Absari', Priyanto ${ }^{2}$, and Muslikhin ${ }^{3}$ \\ ${ }^{1,2}$ Department of Informatics and Electronics Education, Postgraduate Program, Universitas Negeri Yogyakarta, Indonesia \\ ${ }^{3}$ Department of Electrical Engineering, Southern Taiwan University of Science and Technology, Tainan 710, Taiwan \\ E-mail: priyanto@uny.ac.id
}

\begin{abstract}
The study examined the factors affected teachers' Technology, Pedagogy and Content Knowledge (TPACK). Those factors are Technology Knowledge (TK), Pedagogy Knowledge (PK), Content Knowledge (CK) and Technology Pedagogy Knowledge (TPK). Curriculum 2013 has been applying for 5 years. However, an evaluation of how does the teacher deliver learning subjects (pedagogy knowledge), and the implementation of subject mastery (content knowledge) and technology mastery (technology knowledge) is strongly suggested. The study was quantitative with an associative method involving 200 teachers in Salatiga region as samples drawn with simple random sampling. The results of the study showed that PK has a positive effect on TPACK, while TK and CK do not have a positive effect on TPACK. Furthermore, TK, TPK, PK have positive effects on TPK, and TPK has a positive effect on TPACK. This study also suggested that age influences the development of technological knowledge and if one of the knowledge is not possessed by a teacher, the learning process will achieve maximum outcomes.
\end{abstract}

Keywords: analysis, integration technology, TPACK

\section{INTRODUCTION}

In the information age nowadays, information technology sophistication has allowed fast information sharing without being hampered by time and space [1]. It issued various skills to master in this 21 st century. The crucial skills in the 21 st century are still relevant to learning to know, learning to do, learning to be dan learning to live together [2]. Hence, education is expected to provide students mastering those skills to achieve a successful life.

The government policy to apply Curriculum 2013 is a part of an effort to strengthen the education of character in facing the 21 st century [3] because the students have to master the changes of the era along with the development of technology and science. Therefore, students are encouraged to be more active and innovative. While, the role of the teacher shifts from the center of learning to the aspirator and motivator, he only directs or support students so that they have a competency of analysis capability. The teacher is required to be adequate to deliver subject matter properly by using information technology. Moreover, the teacher must learn a lot to improve the skills and competence of learning media. The enhancement of the learning adapted to changes in time and development of technology. Besides, the teacher must have certification of competence so that he will be able to develop himself in enhancing science, technology, and skills through discussion, analysis, and experience sharing.

The results of the interview with several students whose school applied Curriculum 2013 show that there were advantages and disadvantages toward the existence of integration of technology that must be performed in Curriculum 2013. The advantages were the students are more creative and innovative in utilizing the provided technology. On the other hand, it wasted time a lot to create or to develop learning media as the duties of teachers, the media created sometimes are not as optimal as expected.

The observation conducted found various issues on teachers' side caused by Curriculum 2013; mainly they resulted from teachers who do not optimally utilize provided technology. The teachers tend to simply use 
presentations and videos. Furthermore, most teachers are not able to combine content knowledge and other knowledge to be taught in the class. They also are not able to combine pedagogy and other knowledge and use them appropriately in the learning process. Therewith, the teacher was not capable to combine content knowledge, pedagogy, and technology at the same time in the learning process.

Curriculum 2013 has been applying for 5 years. However, there should be an evaluation to assess how the teachers deliver learning subjects (pedagogy knowledge), subject mastery (content knowledge) and technology mastery (technology knowledge); and to ease measurement of integration achievement of TIK by combining the abilities had by the teacher in teaching at schools.

Koehler \& Mishra [4] have developed a framework to assist complex duties to evaluate technology integration in the class known as Technology Pedagogy and Content Knowledge (TPACK). It provides a framework to describe and target the use of technology to improve learning observed by three major components, Technological Knowledge (TK), Pedagogical Knowledge (PK) and Content Knowledge (CK). The framework of TPACK runs further by emphasizing types of knowledge that exist in the intersection of those three major points, such as Pedagogy Content Knowledge (PCK), Technology Content Knowledge (TCK), Technology Pedagogy Knowledge (TPK), Technology Pedagogy and Content Knowledge (TPACK). The framework can be used as a means to do researches to identify how technology is integrated on entire learning in school, by observing the correlation among those components in TPACK [4].

American Library Association (ALA) defines Information literacy as a set of abilities requiring individuals to recognize when information is needed and can locate, evaluate, and use effectively the required information. Information provided in various forms both in print and electronic, in various places such as the library, organization, internet, and media and it is used for academic matters, work, and daily needs. In other words, it can define as an understanding of a set of abilities or skills owned and allow to obtain a solution to solve the problem [5]. It can be concluded that information literacy is an effort to achieve competences for solving the problems. Additionally, the competence itself is a combination of knowledge, ability, and manner. The competence, on the other hand, requires an integrated and continuous training process.

In a more comprehensive scope, information literacy is a program of social empowerment of the information field. Additionally, information science is often associated with the ability to properly access and use the provided information. The ability of information literacy is greatly crucial due to rapid technological progress. The society will be taught a method to search for information and various source of information that continues to grow through information literacy learning. Thus, literacy can assist them widely to find relevant required information fast, and easily. Furthermore, information literacy can increase public knowledge of information currently developing.

Media literacy is the ability to access, analyze, evaluate and send messages in printed and non-printed forms (television, video, movie, advertisement, and internet) [6]. Media literacy is a set of perspective used for actively accessing mass media to interpret a message being faced. Thus, the point is that media literacy attempts to allow critical awareness to society while they are facing media. Critical awareness becomes keywords of media literacy movement. Besides, media literacy itself aims to allow critical awareness towards society so that they become more empowered before the media.

Media literacy allows a guide concerning how to take control of the information provided by media. The more media educate someone, the more capable someone is to see the 
limitation of the real world and the world built by media. In this case, Potter has emphasized that media literacy is constructed by personal locus, knowledge structure, and skill [2]. Personal locus is a purpose and control of information itself. Thus when aware of the information needed, the awareness will require the process of selecting information faster, and vice versa. Knowledge structure is a set of information organized in mind. In media literacy, it needs firm information structure to stand on media effects, media content, media industry, and the real world. Moreover, skill is a means used to improve the ability of media literacy [6].

Technology Pedagogy and Content Knowledge tends to identify the characteristic of knowledge required by the teacher to integrate technology into learning. The point of the framework of TPACK is a complex interaction among three major pieces of knowledge; CK, PK, and TK. The framework of TPACK runs further by emphasizing the type of knowledge that exists at the intersection between the four main forms, namely: PCK, TCK, TPK, and TPACK [4].

Content Knowledge is the teacher's knowledge of subject matters being learned and taught. The knowledge encompasses knowledge concerning the concept, theory, idea, organization framework, and established practice and approach to improve the knowing [7]. Additionally, CK is defined as knowledge concerning subject matter to be learned or taught to students [4], [8]-[11].

Pedagogical Knowledge is a deep knowledge concerning process and practice or learning methods and learning, also how these matters encompass relatively the purposes, values, and learning purposes. Therefore, the pedagogy knowledge requires comprehension about learning theories of cognitive, social, and the development of how to behave towards students in the class [4], [8]-[11].

Technological Knowledge is knowledge concerning standard technology such as book, chalk, and blackboard, and more sophisticated technologies, such as internet and digital video. Knowledge is a certain way of thinking and works with technology, tools, and source of technology [4], [8]-[12].

Pedagogy Content Knowledge is knowledge to know what exactly the appropriate learning approach that content matches, and to know-how elements of content can be reorganized for better teaching. PCK also involves knowledge concerning a learning strategy that combines a proper conceptual representation to solve students' difficulties and misunderstanding and arouse meaningful understanding. It also encompasses knowledge concerning what students convey in the situation of learning, knowledge which may facilitative or dysfunctional for certain assignments [4], [8]-[11]. Technology Content Knowledge is knowledge concerning procedures and content which are reciprocallyrelated. The comprehension of procedures of technology and content influence limit each other [4], [8]-[12].

Technology Pedagogy Knowledge is knowledge concerning existence, component, and capabilities of various techniques used in teaching and learning arrangements and reversely knowing how teaching experiencing changes as the result of the use of certain technologies. It also encompasses knowing the ability and pedagogical limitation of technology for it associates with pedagogical design and strategies at the right time and under its development [4], [8]-[12].

Technology Pedagogy and Content Knowledge is a form of knowledge that arouses over those three components (content, pedagogy, and technology). It underlies meaningful and skilled teaching using technology. TPACK is developed through the intersection of the three components. TPACK is effective basic teaching with technology, that needs comprehension about the representation of constructively use of technical concepts to teach contents, knowledge of what makes the concepts difficult or easy to learn and how do technology can assist to improve several 
problems faced by students, and knowledge of how does it is used to construct the existing knowledge to develop a new epistemology or strengthen its old version consider to rewrite this sentence [4], [8]-[13].

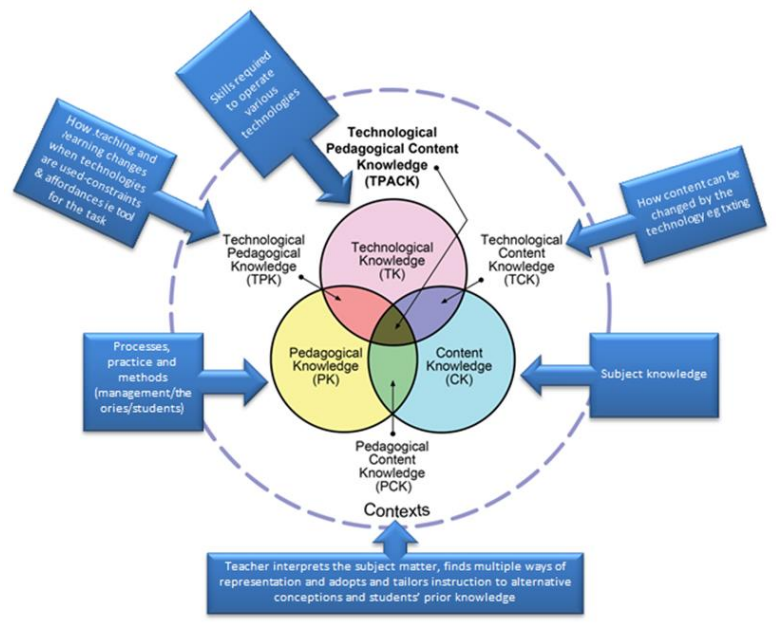

Figure 1. The Framework of TPACK (Koehler \& Mishra)

The study conducted by Tanak proves that there is a significant difference between teacher's TK, TPK, TCK, and TPACK, the result shows that the teachers who have low competence on elements which associated with pedagogy produce a low level of TPACK, which implies has a significant impact on teacher's TPACK [14]. Moreover, Sezer researched to investigate the level of teacher's (Math, Science and Technology, Turkish Literature and Social Science) TPCK competence [15]. Findings of the research show that the teachers in the sample group generally have a high awareness of competence of techno-biology. Additionally, findings show based on the branch and to attend training service program, there is a significant statistically between the level of teacher's awareness of TPCK competence. And, that the level of awareness was not different by gender.

Chuang, et. al. state that the correlation between teacher technology integration practices and Technology Pedagogy and Content Knowledge (TPCK). The correlation between teacher technology integration practices and social media is not significant after it was adjusted to the level of technology integration practices and TIK means. Relatively, teacher practices with TIK mean are the most crucial factor in determining how do the teachers assess TPCK [16]. Furthermore, Hosseini revealed strong evidence that constructionism could help facilitate the development of TPACK. However, by emphasizing effective technology use, further research is needed to track the participants to know how they transfer TPACK into practices in a real classroom [17].

Kopcha et.al. [18] state that the TPACK framework is no doubt as a valuable addition for the teacher education community that holds an important role nowadays of technology integration. The research conducted by Chai proves that the TPACK framework is a generative framework that can lead to a design and evaluation program for pre-service teacher preparation to integrate TIK into teaching and learning in the class [8]. Furthermore, Bas and Senturk in their research show that perception of TPACK of in-service teachers affected by several demographic variables (such as gender, work experiences, educational level, level of teaching, etc.) [19]. Aside from that, in-service teachers who participated in Bas and Senturk research had no adequate perception of TPACK to integrate TIK into teaching efficiently. Therefore, the research seems to show that inservice teachers need training so that they can combine technology, pedagogy, and knowledge content to convey the leaning-teaching process in the class effectively [19].

Likewise, the result of research conducted by Aisyah shows that the development of the TPCK model marked in the learning development of elementary school teacher proved beneficial. It has a good level of validity, practicality, potential effect of the TPACK model marked [20]. Then, another research conducted by Angeli, the competence of TPCK-ICT is significantly improved during one semester. The result of the research shows that theoretical models have been suggested positively affected ICT-TPCK development [21]. 
Based on the review of related kinds of literature, the research aims to answer the following hypothesis. This research emphasizes the use of ICT by developing the ability of teachers to teach, the ability to use technology, the ability to master the content of learning. therefore this study only took six hypotheses.

H1: TK positively affect on TPACK

H2: PK positively affect on TPACK

H3: CK positively affect on TPACK

H4: TK positively affect on TPK

H5: PK positively affect on TPK

H6: TPK positively affect on TPACK

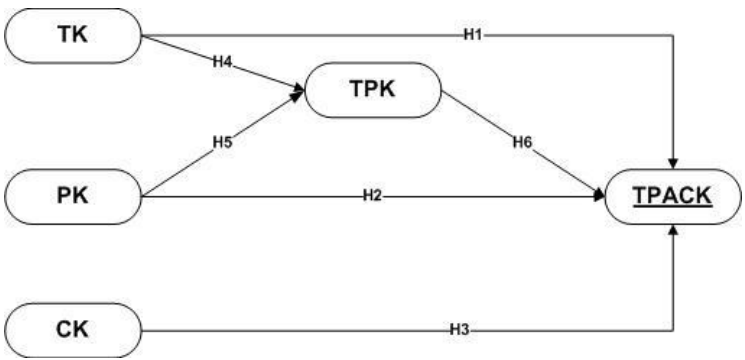

Figure 2. Hypothesis

\section{METHOD}

This is a quantitative study by an associative method to find whether there is a correlation among factors that affect TPACK on teachers. Associative research is the research aims to know the influence and also correlation between two or more variables [22]. The existence of correlation and level of the variable is crucial because by knowing the level of existed correlation, the researcher will be able to develop it following the aim of the research.

The research used a questionnaire as an instrument. It is the data collection method performed by giving several questions or statements to respondents [23]. The developed instrument used a Likert Scale. It is used to measure other's or group's manner, statement, perception concerning social phenomena [24]. The research used a four-point Likert Scale, that is, Scale 1: strongly disagree, 2: disagree, 3 :
Agree, 4: strongly agree. The instrument in this study was developed based on instruments from Mishra \& Koehler [2]. The existing instruments were later added and adjusted to education in Indonesia.

\section{RESULTS AND DISCUSSION}

The study was conducted in March 2018 until April 2018. It encompasses data collection by spreading close questionnaires to several teachers. There were 200 questionnaires have been spread during the research. And, for further calculation prerequisite test and hypothesis test) is used a level of significance $5 \%$ (0.05). The entire data have been obtained and is stated worth analyzing. The data are, then processed using software SPSS and smartPLS.

\begin{tabular}{lllllcc}
\multicolumn{7}{l}{ Table 1. Descriptive Analysis } \\
\hline No & Variable & Sum & Max & Min & Mean & $\begin{array}{c}\text { Standard } \\
\text { Deviation }\end{array}$ \\
\hline 1. & TK & 4225 & 1 & 4 & 3.017857 & 0.622748 \\
2. & PK & 6489 & 1 & 4 & 3.2445 & 0.508772 \\
3. & CK & 4675 & 1 & 4 & 3.339286 & 0.51969 \\
4. & PCK & 4408 & 2 & 4 & 3.148571 & 0.509451 \\
5. & TCK & 4255 & 1 & 4 & 3.039286 & 0.529906 \\
6. & TPK & 4348 & 1 & 4 & 3.105714 & 0.542908 \\
7. & TPACK & 6052 & 1 & 4 & 3.072 & 0.551333 \\
\hline
\end{tabular}

Hypothesis Testing in the study used smartPLS v 3.0. Partial Least Square (PLS) is used to analyze suitable multivariate to explore the correlation between a set of factors. Additionally, PLS is more suitable to analyze a case from small sample sizes. PLS is a strong analytical method for it does not assume the data with a certain measurement scale and require the small number of sample. Therefore, the advantages of using PLS in normal multivariant, it does not need to fulfill. Specifically, the minimum sample required for the PLS approach to obtain the valuable result is ten times from the most complex construct or ten times several independent variables that affect the most complex dependent variable. 


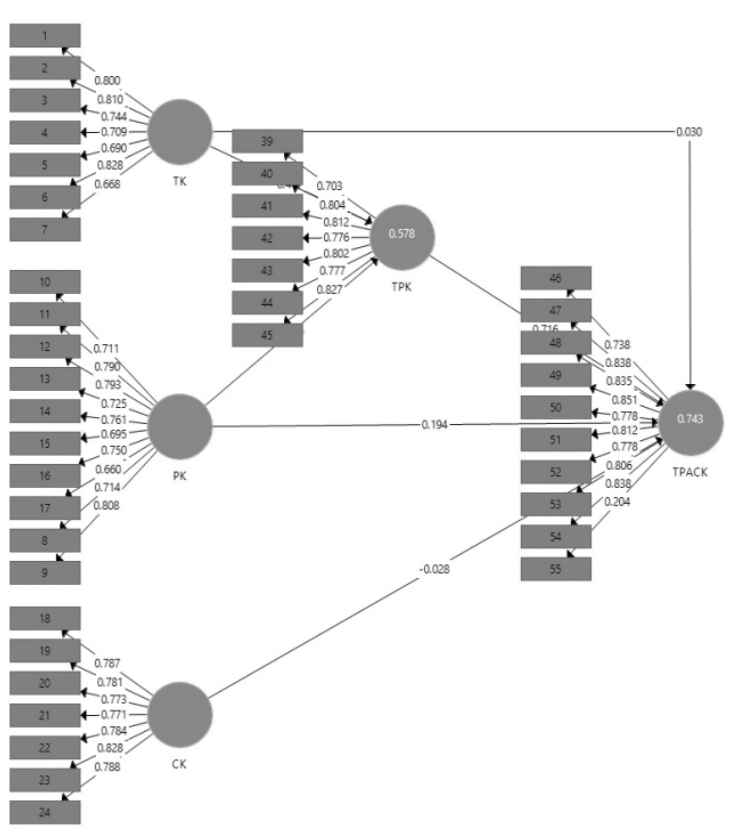

Figure 3. Model Estimation

Besides, the measurement model testing yields strong proof of the strength of the construct level appointed by their internal consistency reliability manifested by their composite reliability. Composite reliability range is 0.8 to 0.9 , and most of the overall indexes are more than the recommended threshold 0.70 , yet, in a research development phase, scale loading 0.5 to 0.6 can be accepted [25]. Likewise, the average of the extracted variant (AVE) for every measure far exceeds the lower suggested threshold 0.50. Smart PLS yields convergent validity tests from the scale by extracting loading factors and cross-loading of overall indicators to each construct.

Table 2. Composite Reliability, Cronbach Alpha and AVE

\begin{tabular}{lcccc}
\hline Construct & $\begin{array}{l}\text { Cronbach's } \\
\text { Alpha }\end{array}$ & rho_A & $\begin{array}{l}\text { Composite } \\
\text { Reliability }\end{array}$ & $\begin{array}{l}\text { Average } \\
\text { Variance } \\
\text { Extracted } \\
\text { (AVE) }\end{array}$ \\
\hline CK & 0.898 & 0.904 & 0.920 & 0.620 \\
PK & 0.909 & 0.914 & 0.924 & 0.551 \\
TK & 0.870 & 0.872 & 0.901 & 0.566 \\
TPK & 0.897 & 0.899 & 0.919 & 0.619 \\
TPACK & 0.915 & 0.936 & 0.932 & 0.593 \\
\hline
\end{tabular}

Inner model testing is performed after evaluating the outer model. It is conducted by observing the R-square of the construct. The value of R2 is 0.67 categorized as substantial (good), R2 $=0.33$ categorized as moderate, R2 value of 0.19 categorized poor and the value of $\mathrm{R} 2>0.70$ categorized as strong.

Inner model testing is done after evaluating the outer model. Inner model testing is done by looking at the $\mathrm{R}$-square in the construct. R2 value of $0.67,0.33,0.19,>0.70$ are categorized as substantial (good), moderate, weak and strong respectively.

\begin{tabular}{ll} 
Table 3. R-square & \\
\hline \multicolumn{1}{c}{ Construct } & R-square \\
\hline TPK & 0.578 \\
TPACK & 0.743 \\
\hline
\end{tabular}

Standard residual of Root Mean Square (SRMR) is measured, it is an average difference among predicted and observed correlation (variances and covariance) based on residual standard deviation. Therefore, it is assumed as a good measurement (model) for PLS-SEM. Considering that SRMR obtained from this research model is 0.063 that show an adequate level of adjustment.

\begin{tabular}{|c|c|c|c|c|c|}
\hline $\begin{array}{l}\text { Hypo } \\
\text { thesis }\end{array}$ & Path & $\begin{array}{c}\text { Path } \\
\text { Coefficient }\end{array}$ & $\begin{array}{c}\mathrm{T} \\
\text { table }\end{array}$ & $\begin{array}{c}\mathrm{T} \\
\text { value }\end{array}$ & Inf. \\
\hline H1 & $\mathrm{TK} \rightarrow \mathrm{TPACK}$ & 0.030 & & 0.455 & Negative \\
\hline $\mathrm{H} 2$ & $\mathrm{PK} \rightarrow \mathrm{TPACK}$ & 0.194 & & 2.446 & Positive \\
\hline $\mathrm{H} 3$ & $\mathrm{CK} \rightarrow \mathrm{TPACK}$ & -0.028 & 1.972 & 0.534 & Negative \\
\hline $\mathrm{H} 4$ & $\mathrm{TK} \rightarrow \mathrm{TPK}$ & 0.467 & & 5.610 & Positive \\
\hline H5 & $\mathrm{PK} \rightarrow \mathrm{TPK}$ & 0.379 & & 5.175 & Positive \\
\hline H6 & ТPК $\rightarrow$ TPACK & 0.716 & & 9.140 & Positive \\
\hline
\end{tabular}

Technology Knowledge does not affect TPACK which $t_{\text {value }}(0.455)<t_{\text {table }}(1.972)$. It means that the variable of Technology Knowledge does not positively affect TPACK. These findings do not support related research of Technology Knowledge affects positively toward TPACK Chai [8], Aisyah [20], Angeli [26]. Yet, it supports research conducted by Bas and Sebturk [19] and Sezer [15] that stated teachers need to train to use the newest technology. In this case, finding the fact that age factor affects someone to know about 
technology. The older the person is, the lowest level of desire to learn about new technologies.

Pedagogy Knowledge affects TPACK which $t_{\text {value }}(2.446)>t_{\text {table }}$ (1.972). It means that the variable of Pedagogy Knowledge positively affects TPACK. This finding supports the research related Pedagogy positively affected TPACK [8], [14], [16], [20], [21]. It proves that the low and high of pedagogy knowledge which had by the teacher in the learning process will affect directly other knowledge, TPACK in this case.

Content Knowledge does not affect TPACK which $t_{\text {value }}(0.534)<t_{\text {table }}(1.972)$. It means that the variable of Content Knowledge does not positively affect TPACK. This finding does not support the research related to Content Knowledge affected positively towards TPACK [8], [20], [21]. Yet, it supports research conducted by Bas \& Senturk [19]. It indicates that subject mastery does not affect significantly the teaching and learning process in the class. The subject being taught is subjects developed by each teacher and the main subject given by the government.

Technology Knowledge affects TPK which $t_{\text {value }}$ 5.610) $>t_{\text {table }}(1.972)$. It means that the variable of Technology Knowledge affects positively to TPK. This finding supports research related to Technology Knowledge affected positively towards TPK that stated the teachers need to train to use recent technology. It proves that knowledge of technology has a significant effect towards teachers' ability in combining knowledge of technology and pedagogy knowledge in teaching and learning process [6], [16], [17], [23], [24], [27], [28].

Pedagogy Knowledge affects TPK which $t_{\text {value }}(5.175)>t_{\text {table }}(1.972)$. It means that the variable of Pedagogy Knowledge positively affected TPK. These findings support the research related to Pedagogy Knowledge positively affects TPK [8], [14], [16], [20], [21]. It proves that Pedagogy Knowledge has a significant effect on teachers' ability in combining Technology Knowledge and
Pedagogy Knowledge in the teaching-learning process in the class.

Technology Pedagogy Knowledge affects TPACK which $t_{\text {value }}(9.140)>t_{\text {table }}(1.972)$. It means that the variable of Technology Pedagogy Knowledge affects positively TPACK. This finding supports the research related Technology Pedagogy Knowledge positively affects TPACK [6], [12], [14]. It proves that Technology Knowledge and Pedagogy Knowledge have a significant effect on teachers' ability in combining technology knowledge, pedagogy knowledge and content knowledge in the teaching and learning process.

From the explanation, it is known that 4 out of the 6 hypotheses are stated to have a positive influence between constructs. While in Hypothesis 1 it is stated that TK has no direct positive effect on TPACK. It means that the level of technological knowledge (TK) possessed by a teacher in the learning process will not directly affect the other knowledge possessed by the teacher, in this case, the teacher's TPACK. Then in Hypothesis 3, it is stated that $\mathrm{CK}$ has no direct positive effect on TPACK. It means that the level of content knowledge possessed by a teacher in the learning process will not directly affect other knowledge that the teacher has, in this case, the teacher's TPACK.

The results of the study have been found several facts that age affects a person to learn new things, in this case learning various new technologies to support the teaching and learning process in the classroom. The solution to this problem is to conduct training facilitated by the government and independently of the initiatives and policies of each school. Besides, another way to do this is that each teacher helps each other when there are difficulties, mutual teaching if there is no understanding of the use of technology to be used. Every teacher tends to master the content to be taught in class. Each teacher develops the subject matter to be taught. The main material from the government is then adjusted and developed to the learning needs. 
The teacher also tends to be able to take control of the class and be able to sort out the appropriate pedagogical approach that is used in class according to the subject matter to be studied. The teacher also sorts out using technology that will be used in the learning process in the classroom. The choice of technology is adjusted to the material to be studied, then from that will make the teacher able to determine the appropriate teaching methods.

\section{CONCLUSION}

The teachers' ability in delivering subjects in the learning process in the class has a significant effect on the ability to combine TK, PK, and CK in the teaching and learning process in the class. The teachers have understood and been able to use various teaching methods in the class. But, in TK and $\mathrm{CK}$, the teachers have not used it maximally. In $\mathrm{TK}$, the age factor affects someone in gaining knowledge of technology. The older the person is, the lower level of desire to learn about recent technologies. On the other hand, in CK, subject mastery fewer influences on the teaching and learning process in the class. The subjects that have been taught are the result of the developed subject by each teacher from the main subject given by the government. Consequently, it can be concluded that the teachers' ability in building students to be creative, innovative and be able to compete with other countries in the information age. Furthermore, the characteristics of the Curriculum 2013 application will be achieved if the teachers can combine TK, CK, and PK in the learning process in the class. If the teachers only master one or two of the knowledge aspects, then the expected result will not be achieved or will not maximally be performed.

\section{REFERENCES}

Pendidikan: Potensi Manfaat, Masyarakat Berbasis Pengetahuan, Pendidikan Nilai, Strategi Implementasi dan Pengembangan Profesional," $J$. Pendidik. Teknol. dan Kejuru., vol. 21, no. 3, pp. 1-1, 2015, doi: 10.21831/jptk.v21i3.3255.

[2] B. P. Y. Combes, "The United Nations Decade of Education for Sustainable Development (2005-2014): Learning to Live Together Sustainably, Applied Environmental," Educ. Commun., vol. 4, no. 3, pp. 215-219, 2005.

[3] G. Gunadi, T. Usman, and B. S. Nugraha, "Identifikasi Kompetensi SMK Program Studi Otomotif dalam Rangka Implementasi Kebijakan Kurikulum 2013," J. Pendidik. Teknol. dan Kejuru., vol. 22, no. 2, pp. 155-162, Oct. 2014, doi: 10.21831/jptk.v22i2. 8923.

[4] P. Mishra and M. J. Koehler, "Technological Pedagogical Content Knowledge: A Framework for Teacher Knowledge," Teach. Coll. Rec., vol. 108, no. 6, pp. 1017-1054, 2006.

[5] E. Fatmawati, The Art of Library: Ikatan Esai Bergizi Tentang Seni Mengolah Perpustakaan. Semarang: Universitas Diponegoro, 2010.

[6] J. W. Potter, Theory of Media Literacy: a Cognitive Approach. California: Sage Publications, 2004.

[7] L. S. Shulman, "Those Who Understand: Knowledge Growth in Teaching," Educ. Res., vol. 15, no. 2, pp. 4-14, 198AD.

[8] C. S. Chai, J. H. Ling Koh, C.-C. Tsai, and L. Lee Wee Tan, "Modeling Primary School Pre-Service Teachers' Technological Pedagogical Content Knowledge (TPACK) for Meaningful Learning with Information and Communication Technology (ICT)," Comput. Educ., vol. 57, no. 1, pp. 11841193, 2011

[9] K. Papanikolaou, E. Gouli, and K. Makri, "Designing Pre-service Teacher Training Based on A Combination of TPACK and Communities of Inquiry," Soc. Behav., vol. 116, pp. 3437-3442., 2014.

[10] F. Boschman, S. McKenney, and J. Voogt, "Ecploring Teachers' Use of 
TPACK in Design Talk: The Collaborative Design of TechnologyRich Early Literacy Activities," Comput. Educ., vol. 82, no. 250-262, 2015.

[11] Y. F. Yeh, Y. S. Hsu, H. K. Wu, and S. P. Chien, "Exploring the Structure of TPACK with Video-Embedded and Discipline-Focused Assessments," Comput. Educ., 2016.

[12] Z. Abidin, "Strategi Pembelajaran di Perguruan Tinggi (Optimalisasi Kinerja Dosen alam Pembelajaran di Fakultas Agama Islam Universitas Muhammadiyah Surakarta)," SUHUF, vol. XVII, pp. 75-80, 2005.

[13] S. J. Jang, "Integrating the Interactive Whiteboard and Peer Coaching To Develop the TPACK of Secondary Science Teachers," Comput. Educ., vol. 22, pp. 1744-1751, 2010.

[14] A. Tanak, "Designing TPACK-based Course for Preparing Student Teachers to Teach Science with Technological Pedagogical Content Knowledge," Kasetsart J. Soc. Sci., vol. 41, no. 1, 2018.

[15] B. Sezer, "Examining Techno pedagogical Knowledge Competencies of Teachers in Terms of Some Variables," Soc. Behav. Sci., vol. 174, pp. 208-215, 2015.

[16] H. H. Chuang, C. Y. Weng, and F. C. Huang, "A Structure Equation Model Among Factors of Teacher' Technology Integration Practice and Their TPCK," Comput. Educ., vol. 86, pp. 182-191, 2015.

[17] Z. Hosseini, "Development of Technological Pedagogical Content Knowledge through Constructionist Activities," Soc. Behav. Sci., vol. 182, pp. 98-103, 2015.

[18] T. J. Kopcha, A. Ottenbreit-Leftwich, and J. Jung, "Examining the TPACK Framework Through the Convergent and Discriminant Validity of Two
Measures," Comput. Educ., vol. 78, pp. 87-96, 2014.

[19] G. Bas and C. Senturk, "An Evaluation of Technological Pedagogical Content Knowledge (TPACK) of In-Service Teachers: A Study in Turkish Public Schools," Int. J. Educ. Technol., vol. 52, pp. 46-58, 2018.

[20] R. Aisyah A, "The Development of Working Design through Characterized Technology Pedagogy and Content Knowledge in the Elementary Schools' Instructional," Procedia - Soc. Behav. Sci., vol. 103, pp. 1016 - 1020, 2013.

[21] C. Angeli and N. Valanides, "Epistemological and Methodological Issues for the Conceptualization, Development, and Assessment of ICTTPCK: Advances in Technological Pedagogical Content Knowledge (TPCK)," Comput. Educ., vol. 52, pp. 154-168, 2009.

[22] Sugiyono, Metodelogi Penelitian Kuantitatif, Kualitatif Dan $R \& D$. Bandung: Alfabeta, 2013.

[23] J. Hendri, Merancang Kuesioner. Jakarta: Universitas Gunadarma, 2009.

[24] Sugiyono, Metode Penelitian Kuantitatif Kualitatif dan $R \& D$. Bandung: Alfabeta, 2014.

[25] I. Ghozali, Aplikasi analisis Multivariate dengan Program SPSS. Semarang: Badan Penerbit UNDIP, 2014.

[26] Hamzah B Uno, Teori Motivasi dan Pengukurannya. Jakarta : Bumi Aksara, 2014.

[27] A. Toynbee, Sejarah Umat Manusia (Mankind and Mother Earth): A Narrative History of the World. Yogyakarta: Pustaka Pelajar, 2004.

[28] Y. Miarso, Menyemai Benih Teknologi Pendidikan. Jakarta: Prenada Media, 2004. 